Article

\title{
Climate Change and Sustaining Heritage Resources: A Framework for Boosting Cultural and Natural Heritage Conservation in Central Italy
}

\author{
Ahmadreza Shirvani Dastgerdi ${ }^{1, * \mathbb{C}}$, Massimo Sargolini ${ }^{1}{ }^{(\mathbb{D}}$, Shorna Broussard Allred ${ }^{2}$, \\ Allison Chatrchyan ${ }^{3}$ and Giuseppe De Luca ${ }^{4}$ (D) \\ 1 School of Architecture and Design, University of Camerino, 63100 Ascoli Piceno, Italy; \\ massimo.sargolini@unicam.it \\ 2 Center for Conservation Social Sciences, Department of Natural Resources \& Southeast Asia Program, \\ Cornell University, Ithaca, NY 14853, USA; srb237@cornell.edu \\ 3 Department of Development Sociology, Cornell University, Ithaca, NY 14853, USA; amc256@cornell.edu \\ 4 School of Urban and Regional Planning, University of Florence, 50121 Firenze, Italy; giuseppe.deluca@unifi.it \\ * Correspondence: ahmadreza.shirvani@unicam.it
}

Received: 9 January 2020; Accepted: 31 January 2020; Published: 5 February 2020

check for updates

\begin{abstract}
Climate change has dramatically affected the rainfall patterns and water systems in Central Italy. The vulnerability of this area to climate change and natural hazards necessitates that appropriate adaptation policies be put in place to protect heritage sites. This study aims to develop a cultural and natural heritage conservation framework for Central Italy that enhances the capacity of climate change adaptation for heritage resources. For this purpose, a comparison was made between the UNESCO (United National Educational, Scientific and Cultural Organization) Convention of 1972 and the European Landscape Convention of the Council of Europe to achieve a coherent vision for the protection of heritage resources in Europe. After describing the impacts of climate change on heritage resources in Central Italy, we analyze and suggest improvements to the conservation framework for wisely protecting heritage resources in a changing climate. The findings reveal that conservation sectors require assessments of the value of heritage resources at the territorial scale to effectively define conservation priorities, assess the vulnerabilities, and more precisely direct funding. In this respect, the integration of the European Landscape Convention with territorial planning may boost the unity of a conservation framework in terms of climate change while providing new opportunities for conservation authorities to develop adaptation policies.
\end{abstract}

Keywords: climate change; heritage resources; conservation; adaptation capacity; territorial planning

\section{Introduction}

Heritage resources include all cultural and natural sites, and in particular, World Heritage Sites. As designated by UNESCO (United National Educational, Scientific and Cultural Organization), World Heritage Sites are a type of "cultural landscape" that conserve cultural and natural heritage sites around the world [1]. Each World Heritage site is designated on the basis of one or more Outstanding Universal Values [2], which are assessed through a rigorous evaluation process by the Advisory Bodies of the World Heritage Convention [3]. According to article 49 of the convention, Outstanding Universal Value is defined as "cultural and/or natural significance which is so exceptional as to transcend national boundaries and to be of common importance for present and future generations of all humanity" [4]. As a type of cultural landscape, World Heritage Sites prominently boost the economy of countries by attracting numerous domestic or international visitors [5]. From a broader perspective, Plachter and Rossler (1995) define cultural landscapes as the result of "the interactions between people and 
their natural environment over space and time" [1]. In cultural landscapes, heritage resources recall historical identities and enhance social cohesion [6].

From a territorial planning point of view, there is a strong tie between the proper conservation of heritage resources and the sustainability of cultural landscapes [7-9]. Heritage resources were often created based on a stable climatic condition [10]. However, global climate change-which is causing increases in extreme weather events-has emerged as a significant threat to the sustainability of many heritage resources all over the world [11,12].

Climate change inflicts direct damage on the materials and structure of historical monuments [13] and threatens the status of Outstanding Universal Value at many World Heritage Sites [14]. For instance, the United Kingdom Climate Impacts Programme (UKCIP) has suggested that the sea level rise in the Thames Estuary will reach between 0.26 and $0.86 \mathrm{~m}$ by the year 2080, compared to its average level between 1961 and 1990 [15]. Such a rise in sea level and projected changes in storm patterns will pose a significant threat to the Outstanding Universal Value of three World Heritage sites in London, including the Tower of London, the Palace of Westminster, and Maritime Greenwich [10]. Furthermore, climate change has indirect impacts, such as severe weather events that diminish the number of visitors [16] and disrupt socio-economic activities at cultural landscape areas [17]. For example, climate change is projected to decrease the annual visitations numbers of the Mesa Verde National Park in the USA, which attracts about 500,000 tourists yearly and contributes about US $\$ 47$ million to the local economy [18].

According to Intergovernmental Panel on Climate Change (2014), adaptation is the process of adjustment to actual or expected climate and its effects. In human systems, adaptation seeks to moderate or avoid harm while harnessing beneficial opportunities [19]. Thus, climate adaptation involves the actions taken to address the impacts of climate change by reducing vulnerability and taking advantage of opportunities. Climate adaptation actions have the potential to reduce governmental barriers and create an environment in which private sector actors can invest in adaptation strategies fit for a future without carbon [20]. Many cities and mega-cities have improved their climate adaptation capacity through policymaking and have developed adaptation measures for reducing vulnerability to the effects of climate change [21]. In this respect, Dilling (2017) explains how cities in the USA have successfully used policymaking to cope with climate and water variability and increasing population [22].

Building adaptation capacity may be defined at various levels (i.e., international, national, or local), and subnational jurisdictions are essential sectors for improving measures to reduce the risks of climate change [23]. The adaptation capacity at each level plays a vital role in the effectiveness of adaptation policies in the long-term [24].

Heritage resources are easily vulnerable to climate-related risks, such as heavy rainfall events, or landslides (UNESCO, 2008). A proper understanding of climate impacts on heritage resources not only provides a reliable base for formulating and developing adaptation policies, but it can also help to reduce the costs of climate change impacts, by building adaptive capacity to conserve those resources (Galeotti and Roson, 2012). Therefore, an inter-disciplinary framework is needed to effectively addresses the complex interactions between climate, physical, social, and ecological systems [25]. Delayed action in the present may diminish opportunities for adaptation pathways in the future [26]. Many cultural heritage experts and researchers in Europe believe that the adaptation of heritage resources to climate change is possible [27].

Local case studies that analyzed the adaptive capacity of a particular region or a community argue for the need to assess and measure adaptive capacity at the regional or local level because the decisions to adapt are often made at that level [28,29]. Building on the IPCC's definition of adaptive capacity, Smit and Pilifosova classify the determinants of adaptive capacity in six categories, consisting of Economic Resources, Technology, Infrastructure, Information and Skills, Institutions, and Equity [30]. It is widely accepted that economic assets, capital resources, financial means and wealth all play an important role in adaptive capacity. Wealthy nations are more likely to be in a better position to adapt to changes in the climate and can bring more resources to bear on the costs of adaptation. Technological resources 
enable adaptation options, and consequently the lack of access and development of technology can lead to lower adaptive capacity. Existence and development of infrastructure can form the basis for the development of adaptation options and measures. Skilled, informed, and trained personnel enhance adaptive capacity and access to information is likely to lead to development of adaptation options that are timely and appropriate. Well-developed institutions and governance structures not only have the capacity to address present day challenges but also provide a decision-making infrastructure that enables communities to effectively plan for future. Finally, equity is a measurement tool for social sensitivity to climate change and pays needed attention to populations most vulnerable to climate change impacts [31]. Some studies also highlight the necessity of developing communication mechanisms among heritage institutions, academic researchers, and the local community to build adaptation capacity at heritage sites $[13,32]$. Communication is essential for adapting to climate change because it facilitates the engagement of the public in climate change science and solutions in partnership with governments, media organizations, companies, and civil society [33].

In Italy, heritage resources play a significant role in social cohesion as markers of historical identity and are also a driving factor in the national economy. In this respect, The Italian National Institute of Statistics affirms that in 2017 visitors spent about 421 million nights at tourist accommodations, which represents an increase of $4.4 \%$ in comparison with the past year. However, few studies warn about the adverse economic impacts of climate change on Central Italy's heritage tourism. Yet the climate is changing; for example, climatic data shows that 2008 was recorded as the third wettest year in Italy since 1961 [34]. Thus, urgent attention is needed to develop mitigation and adaptation policies that take heritage resources into account.

Tourism and agricultural production are the most vulnerable economic sectors in Central Italy to climate change [35]. A recent World Bank report also highlights Italy's considerable vulnerability to climate change in the coming decades [36]. Heritage resource conservation remains a concern due to extreme events (droughts, flooding, and landslides), which are increasing in Central Italy as they are in many other regions of the world [37]. Therefore, the long-term sustainability of heritage resources in Central Italy requires a robust conservation framework that enhances the adaptation capacity in this region. This study aims to develop a resilient framework that can be used to assess the adverse climate impacts on cultural and natural heritage sites in Central Italy, and bring new opportunities for adaptation of heritage resources to climate change.

\section{Research Design}

\subsection{Materials and Methods}

This study adopts a descriptive qualitative comparative approach for boosting the current cultural and natural heritage conservation framework in Central Italy. For this purpose, we first compare two heritage conservation frameworks in Italy-the UNESCO Convention of 1972 and the European Landscape Convention of the Council of Europe-to achieve a coherent vision for the protection of heritage resources in Europe, and in particular, Italy. In the results, the impacts of climate change on various heritage resources are discussed to provide an understanding of the conservation challenges in Central Italy. Finally, we propose a roadmap for promoting the cultural and natural heritage conservation framework and building capacity for adaptation of heritage resources to climate change in this area.

\subsection{Study Area}

Italy is characterized by a very complex climatic formation due to the presence of high mountain ranges, such as the Alps and Apennines, and the vicinity of the Mediterranean Sea. Regarding the atmospheric circulation, the Mediterranean Sea and land area of Italy are generally influenced by tropical air masses in the summer and by western air masses in winter. The variability of these circulation patterns and the interactions with such a complex system make the Mediterranean region 
especially vulnerable to climate change and sensitive both to the global phenomena and to events at the local scale [38].

This study focuses on Central Italy, which is one of the five macro regions of the country, with a total area of $58,085 \mathrm{~km}^{2}$. Central Italy is composed of the four regions of Tuscany, Lazio, Umbria, and Marche [39]. Central Italy is dominated by the hills and mountains of the Apennines, from which a few major rivers flow. There are few natural plains of any size in this region, but those that do exist are famously fertile. They have been supplemented over the years by a process of land reclamation that has turned the coastal swamps and marshes into highly productive agricultural land, and provided space for the expansion of cities and towns [40]. With 55 World Heritage Sites, Italy is a leader under the UNESCO World Heritage List, and Central Italy hosts 13 World Heritage Sites (Figure 1 and Table 1) [41].
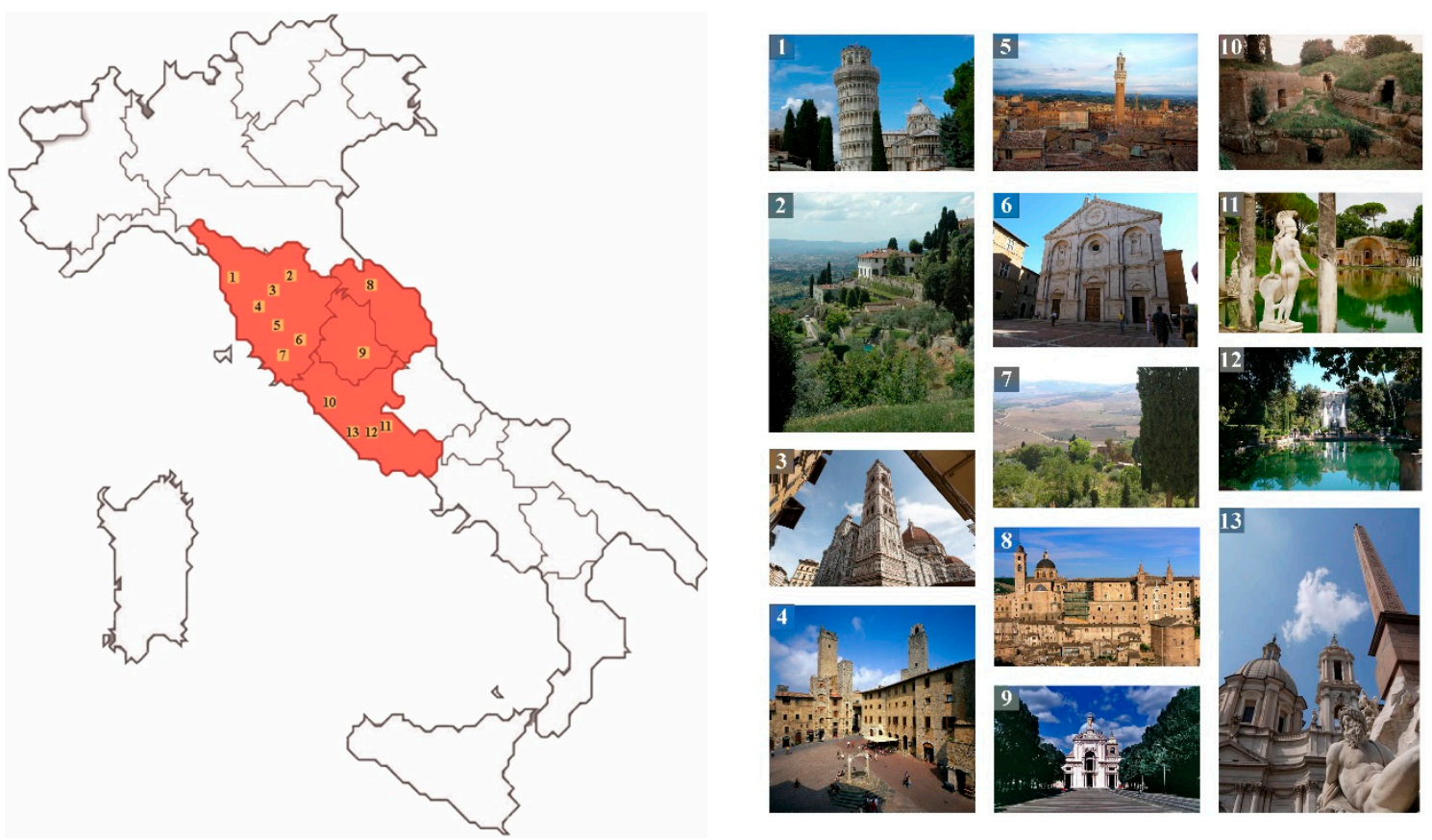

Figure 1. World heritage sites in Central Italy [42]

Table 1. World Heritage Sites in Central Italy [43].

\begin{tabular}{|c|c|c|c|}
\hline Pr. & World Heritage Site & Year of Inscription & Category of Inscription \\
\hline \multirow{5}{*}{ Tuscany } & 1. Piazza del Duomo, Pisa & 1987 & (i)(ii)(iv)(vi) \\
\hline & 2. Medici Villas and Gardens & 2013 & (ii)(iv)(vi) \\
\hline & 4. Historic Centre of San Gimignano & 1990 & (i)(iii)(iv) \\
\hline & 5. Historic Centre of Siena & 1995 & (i)(ii)(iv) \\
\hline & 7. Val d'Orcia & 2004 & (iv)(vi) \\
\hline Marche & 8. Historic Centre of Urbino & 1998 & (ii), (iv) \\
\hline Umbria & 9. Assisi, the Basilica of San Francesco and Other Franciscan Sites & 2000 & (i), (ii), (iii), (iv), (vi) \\
\hline Lazio & 10. Etruscan Necropolises of Cerveteri and Tarquinia & 2004 & (i)(iii)(iv) \\
\hline
\end{tabular}

Many of these sites are valuable treasures of the medieval and Renaissance era (Table 1), which meet different criteria of Outstanding Universal Value (Table 2). 
Table 2. The Criteria for Outstanding Universal Value Based on the Operational Guidelines for the Implementation of the World Heritage Convention [4].

\begin{tabular}{|c|c|c|}
\hline Type & Criteria & Definition \\
\hline \multirow{5}{*}{ Cultural } & (i) & to represent a masterpiece of human creative genius \\
\hline & (ii) & $\begin{array}{l}\text { to exhibit an important interchange of human values, over a span of time or } \\
\text { within a cultural area of the world, on developments in architecture or } \\
\text { technology, monumental arts, town-planning or landscape design }\end{array}$ \\
\hline & (iii) & $\begin{array}{l}\text { to bear a unique or at least exceptional testimony to a cultural tradition or to a } \\
\text { civilization which is living or which has disappeared }\end{array}$ \\
\hline & (iv) & $\begin{array}{l}\text { to be an outstanding example of a type of building, architectural or } \\
\text { technological ensemble or landscape which illustrates (a) significant stage(s) in } \\
\text { human history }\end{array}$ \\
\hline & (v) & $\begin{array}{l}\text { to be an outstanding example of a traditional human settlement, land-use, or } \\
\text { sea-use which is representative of a culture (or cultures), or human interaction } \\
\text { with the environment especially when it has become vulnerable under the } \\
\text { impact of irreversible change }\end{array}$ \\
\hline \multirow{5}{*}{ Natural } & (vi) & $\begin{array}{l}\text { To be directly or tangibly associated with events or living traditions, with ideas, } \\
\text { or with beliefs, with artistic and literary works of outstanding universal } \\
\text { significance. }\end{array}$ \\
\hline & (vii) & $\begin{array}{l}\text { to contain superlative natural phenomena or areas of exceptional natural } \\
\text { beauty and aesthetic importance }\end{array}$ \\
\hline & (viii) & $\begin{array}{l}\text { to be outstanding examples representing major stages of earth's history, } \\
\text { including the record of life, significant on-going geological processes in the } \\
\text { development of landforms, or significant geomorphic or physiographic features }\end{array}$ \\
\hline & (ix) & $\begin{array}{l}\text { to be outstanding examples representing significant on-going ecological and } \\
\text { biological processes in the evolution and development of terrestrial, fresh } \\
\text { water, coastal and marine ecosystems and communities of plants and animals }\end{array}$ \\
\hline & $(\mathrm{x})$ & $\begin{array}{l}\text { to contain the most important and significant natural habitats for in situ } \\
\text { conservation of biological diversity, including those containing threatened } \\
\text { species of Outstanding Universal Value from the point of view of science or } \\
\text { conservation }\end{array}$ \\
\hline
\end{tabular}

\section{Analysis and Results}

\subsection{Landscape as a Cultural Heritage}

The strong tie between cultural and natural heritage sites is evident in many "cultural landscapes" in Italy, and in particular, in Central Italy where there is a harmonious combination between many small historic centers and their natural heritage and natural resources. For instance, the landscape of Val d'Orcia in the province of Siena in Tuscany is part of the agricultural hinterland of Siena, redrawn and developed when it was integrated into the territory of the city-state in the 14th and 15th centuries to reflect an idealized model of good governance. The landscape of the Val d'Orcia was celebrated by painters from the Siennese School, which flourished during the Renaissance. Images of the Val d'Orcia, and particularly depictions of landscapes where people are drawn as living in harmony with nature, have come to be seen as icons of the Renaissance and have profoundly influenced the development of landscape thinking [44].

The palace and the gardens of Villa d'Este in Tivoli, in the center of Italy, is another example of this harmonious combination. The Villa d'Este had a profound influence on the development of garden design throughout Europe. The gardens with the fountains are a masterpiece of hydraulic engineering, both for the general layout of the plan and the complex system of distribution of water. A broad area around the Villa is protected as landscape by a law decree (Decreto n.42/04) to be of interest for the landscape resources [45]. 
To promote the meaning of cultural heritage, the Italian Ministry of Cultural Heritage and Activities adopts a "landscape vision" as a mixture of cultural goods and landscape resources [46]. As climate change impacts the features of the landscape, the cultural and natural heritage conservation framework should be able to assess the importance and vulnerability of heritage resources at the early stages of communication and policy making [25]. Despite having a mutual goal of heritage conservation, the approaches of the two conventions (UNESCO Convention of 1972 and Europe Landscape Convention) are distinct, which leads to different definitions of cultural and natural landscapes, and consequently, different heritage policies.

\subsection{Approaches for Cultural Landscape}

In the UNESCO 1972 Convention, the heritage concept is divided into two independent and separate notions of cultural and natural heritage. According to Articles one and two of the UNESCO Convention, cultural heritage is defined as monuments and groups of buildings and sites that have historical, aesthetic, archaeological, scientific, ethnological, or anthropological value. Natural heritage is defined as exceptional physical, biological, and geological formations, habitats of threatened animal and plant species, and areas that have scientific or aesthetic value [47]. The cultural criteria were slightly revised to the "cultural landscape" in the Operational Guidelines for the Implementation of the World Heritage Convention in 1992, albeit the origin of the concept harkens back to Carl O. Sauer in 1925 [48]. As shown in Table 3, UNESCO categorizes cultural landscapes into three types [49]. In the vision of UNESCO, historical features are a vital factor for the maintenance and inscription of a cultural landscape on the World Heritage list. For instance, the presence of traditional crops and local products, as well as the presence of architecture related to agricultural activities, are considered by UNESCO to be the significant factors of integrity in a cultural landscape. However, problems arise in determining how best to quantify the threshold of traditional features or historical durability in a changing climate. Furthermore, maintaining the integrity of the heritage sites is strongly influenced by social and economic factors.

Table 3. UNESCO Categories for Cultural Landscape.

\begin{tabular}{|c|c|c|}
\hline Cat. & Type of Cultural Landscape & Definition \\
\hline (i) & Clearly defined & $\begin{array}{l}\text { Designed and created intentionally by man. This embraces } \\
\text { garden and parkland landscapes characteristically constructed } \\
\text { for aesthetic, social and recreational reasons which are often } \\
\text { associated with religious or other monumental buildings and } \\
\text { ensembles }\end{array}$ \\
\hline (ii) & Organically evolved & $\begin{array}{l}\text { Fall into two sub-categories. First, a relict landscape is one in } \\
\text { which an evolutionary process came to an end at some time in } \\
\text { the past. Second, is one which retains an active social role in } \\
\text { contemporary society closely associated with a traditional way } \\
\text { of life. }\end{array}$ \\
\hline (iii) & Associative cultural & $\begin{array}{l}\text { Landscapes with definable powerful, religious, artistic, or } \\
\text { cultural associations with the natural element rather than } \\
\text { material cultural evidence. }\end{array}$ \\
\hline
\end{tabular}

The European Landscape Convention - which was adopted in Florence in 2000-is the first international agreement exclusively dedicated to the cultural landscape. It describes the cultural landscape as any part of the territory "as perceived by people, whose character is the result of the action and interaction of natural and human factors" [50]. The convention emphasizes that landscape is derived from the interaction of a community and its environment over time. The vision of the European Landscape Convention is different from the UNESCO Convention, because its approach to cultural landscape is a quality of each territory, not only of those with exceptional landscape values. While the European Landscape Convention is more regionally focused and takes into consideration a holistic and social landscape, the UNESCO 
Convention seeks to protect only those landscapes which are recognized worldwide as an exceptional heritage [51].

Before developing disconnected climate adaptation policies, there is value in determining what distinguishes buildings, landscapes, and other aspects of community into a unique culture. Furthermore, the cultural landscape is not so much something that is particularly beautiful or exceptional, but rather different and unique. Thus, it is necessary to sensitize and sufficiently educate both governments and communities about the value of cultural landscapes and involve them in heritage planning [52]. This approach gathers assets of agricultural and forestry interests, architectural assets, and cultural traditions in a distinctive or characteristic set. The cultural landscape approach meets both natural heritage and cultural heritage, within which we must consider not only the agricultural or forest heritage, but also the architectural aspects, including archaeological sites [53]. Therefore, adopting the approach of the European Landscape Convention is more fitting for defining a more grounded concept of cultural heritage in Central Italy and thus building climate adaptation capacity in this area [54].

\subsection{Climate Change Impacts in Central Italy}

Climate change and its related natural risks can disrupt the socio-economic dynamics in cultural landscapes. According to the Italian National Institute of Statistics [55], the average annual temperature of the country over the time period from $2002-2016$ was $15.5^{\circ} \mathrm{C}$, an increase of $1.0^{\circ} \mathrm{C}$ when compared to the years 1971-2000. In the period from 2002-2016, there were, on average, 110 summer days and 45 tropical nights; this is, respectively, 17 and 14 more than the climatological average for Italy. Climate observations confirm an increase in the average monthly temperature as well as an upward trend in extreme temperatures (Figure 2). In Tuscany, for instance, the maximum temperature increase $\left(+0.44{ }^{\circ} \mathrm{C} /\right.$ decade $)$ was slightly higher than minimum temperature $\left(+0.38^{\circ} \mathrm{C} /\right.$ decade $)$ and, consequently, an increase in summer daily temperature range was noted $\left(+0.06^{\circ} \mathrm{C} /\right.$ decade $)$ [56].

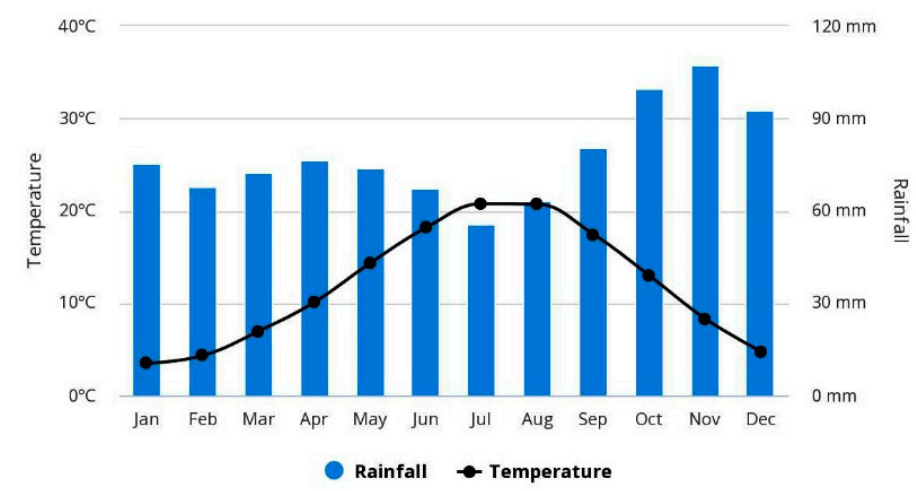

Figure 2. Average monthly temperature and precipitation in Italy from 1901-2016 [57].

In Central Italy, floods and landslides are among the leading risks that may impose irreparable damage to cultural landscapes (Figure 3). In this sense, the intangible characteristics of the cultural landscape may be threatened by loss of inhabitants due to damage to infrastructure, the spread of pollution and water-related diseases, soil erosion, and damage to agricultural lands and crops. For instance, between 1939 and 2004, Italy was hit by 28 massive floods that affected 2.85 million people and caused 1.5 million to become homeless. The number of victims over this time period was 694 people, and the cost of these climate impacts was estimated at US\$32.7 million. After the floods of Campania in May 1998, climate risks were exacerbated by naturally occurring disasters in the region, such as the 2016 earthquake in Central Italy that devastated heritage resources and claimed the lives of nearly 300 people. In response, Italy developed a national plan "Urgent measures for the prevention of hydrogeological risk and for areas affected by landslides in the Campania region" under the law 267/98 for reducing the risks of floods and landslides [58]. However, this law does not take into account the higher risks deriving from climate change scenarios, for which no assessment currently exists [59]. 

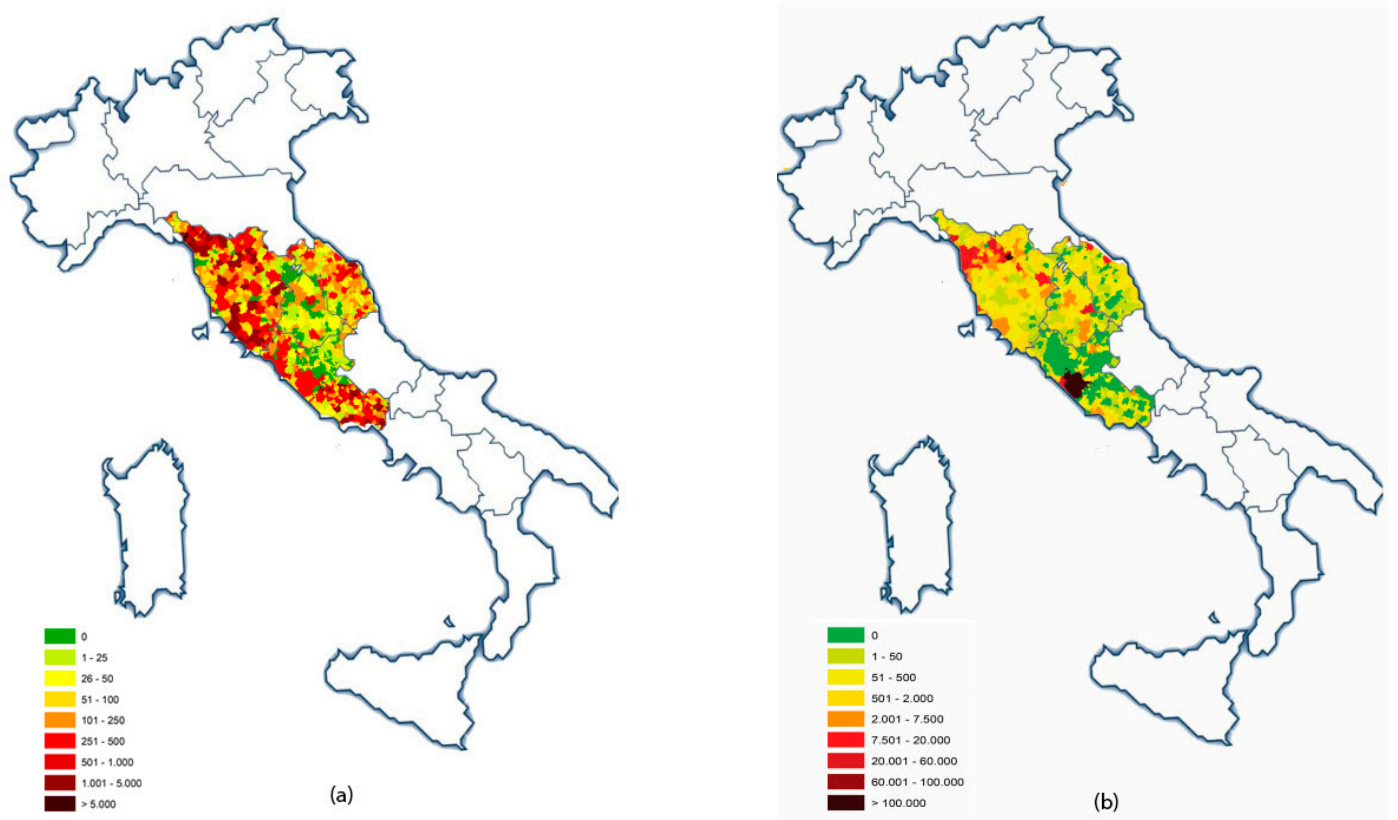

Figure 3. (a) The population at risk of landslides in Central Italy; (b) The population at risk of floods in Central Italy, derived from [60].

The risks of severe weather patterns caused by climate change may lead to irreversible damages to the value of many heritage resources in Central Italy. These threats affect not only the identity of the landscape but also the tourism industry. The tourism activity and economy may be interrupted or diverted, at least until livable conditions are restored in areas affected by floods or landslides.

Another concern is the loss of biodiversity and natural ecosystems due to the impacts of climate change. Natural resources are an integral part of the identity of territories in Italy. Moreover, in Central Italy, cultural landscapes encompass many of Natura 2000 sites, which include the most valuable and threatened species and habitats in Europe. In the region of Umbria, for instance, Natura 2000 sites cover about $15 \%$ of the entire territory. The sites encompass 41 habitats of European interest, of which 11 are defined as rare species, with 143 animal species (four are defined as primary), and eight species of plants [61].

The Italian public is mostly aware of the seriousness of climate change, but climate change is considered less urgent than other matters of concern related to the economic situation [62], specifically in terms of conservation policies. In developing adaptation capacity in cultural landscapes, Italian citizens rely mainly on information provided by traditional mass media, while environmental organizations and public communication by scientists play a marginal role. Some studies developed cyberinfrastructure models for disaster management [63].

\section{Discussion}

The current vision in Central Italy for conservation and management of heritage resources is still very close to the traditional paradigm that affords tangible heritage areas an intrinsic value, worthy of great efforts for its collection, catalogue and preservation in view of the likely restoration of the damaged heritage [64]. However, both protection of heritage areas and climate change adaptation are dynamic fields of investigation [65]. Prior to developing climate adaptation policies, it is necessary to examine the meaning of cultural heritage in light of climate change. According to the results, viewing heritage resources with a broader lens of the cultural landscape provides a comprehensive framework for the wise development of adaptation policies. In the vision of UNESCO, historical features play 
a vital role in the definition of the cultural landscape and can be divided into three different categories, including (1) clearly defined; (2) organically evolved; and (3) associatively cultural.

In contrast, the European Landscape Convention focuses on the social values of the cultural landscape that make a community distinct and unique. In this vision, the cultural landscape provides a holistic perspective - an area, as perceived by people, whose character is the result of the action and interaction of human factors and natural resources therein. Furthermore, in this vision, the local economy is linked to landscape resources in several ways: through resources related to the production of food, energy, raw material, and water (farming, forestry, fishery, water supply) and through the tourism industry. The European Landscape Convention promotes a valuation system based on community perception. It also pays particular attention to the strategic role of cultural and natural goods in sustaining the cultural landscape. From a territorial planning point of view, cultural heritage may be defined as a system of synergistic relationships between unique qualities of the physical environment, the built environment, and the anthropic environment [66]. Therefore, adaptation policies should be developed under a cultural and natural heritage conservation framework that suitably recognizes these three aspects in an integrated form.

The analysis of climate change impacts on Central Italy (Figure 3) illustrates the varying vulnerability to natural risks across the landscape. From a territorial planning point of view, developing climate-adaptive policy and reducing the impacts of natural risks is not only about conservation of the physical features in a heritage site, but also recognizing and protecting socio-economic activities that are linked to the cultural, natural, or World Heritage Sites. The socio-economic changes associated with climate impacts can have a significant influence on the protection of the cultural landscape. For identification of climate change impacts on socio-economic dynamics, heritage sectors need to estimate the damage costs of climate change on the cultural landscape and be fully aware of how this damage can be minimized by adaptation policies that build capacity and resilience. Such a vision would enhance the concept of cultural heritage from an isolated site into a territorial resource.

To promote the adaptation capacity of cultural landscapes, it is recommended that Central Italy integrate the European Landscape Convention within territorial planning systems. Such a combination provides an opportunity to use multidisciplinary and multi-sector perspectives in dealing with protection challenges, while also considering the unique morphologies of cultural landscapes in this area. For instance, if agriculture factors centrally in the identity of a cultural landscape, understanding farmers' views, framing issues, and necessary actions would be crucial for developing climate adaptation policies [54]. Adopting a territorial vision in a cultural and natural heritage conservation framework facilitates the inclusion of new approaches for adaptation of heritage resources in the face of climate change. The proposed approach supports multi-scale and multi-sector actions rooted in the differing expectations of a wide range of partners and expands the scope of community participation and engagement.

Consequently, territorial planning facilitates communication between planning institutions, stakeholders, and researchers in developing adaptation policies and reducing the risks of climate change. Furthermore, in this vision, cultural and natural heritage goods are dynamically assessed as useful characteristics for the sustainability of the cultural landscape. Adopting a territorial approach to heritage resources from conservation to protection, static to dynamic, valued to valuing, and from isolated to contributor can play a fundamental role in adaptation to climate change in Central Italy.

The proposed cultural and natural heritage conservation framework (Figure 4) not only supports mitigation and adaptation strategies at the national scale but also boosts communication among heritage institutions, academic researchers, and the local community. However, developing and implementing adaptation policies in such a framework highlights the need for further research to address the potential challenges and risks. Although this model affirms that losing a part of heritage resources because of climate change impacts is inevitable, inadequate knowledge of how vulnerabilities and the cost of climate change should be prioritized in the context of a cultural landscape remains a challenge for developing climate-adaptive policies. 


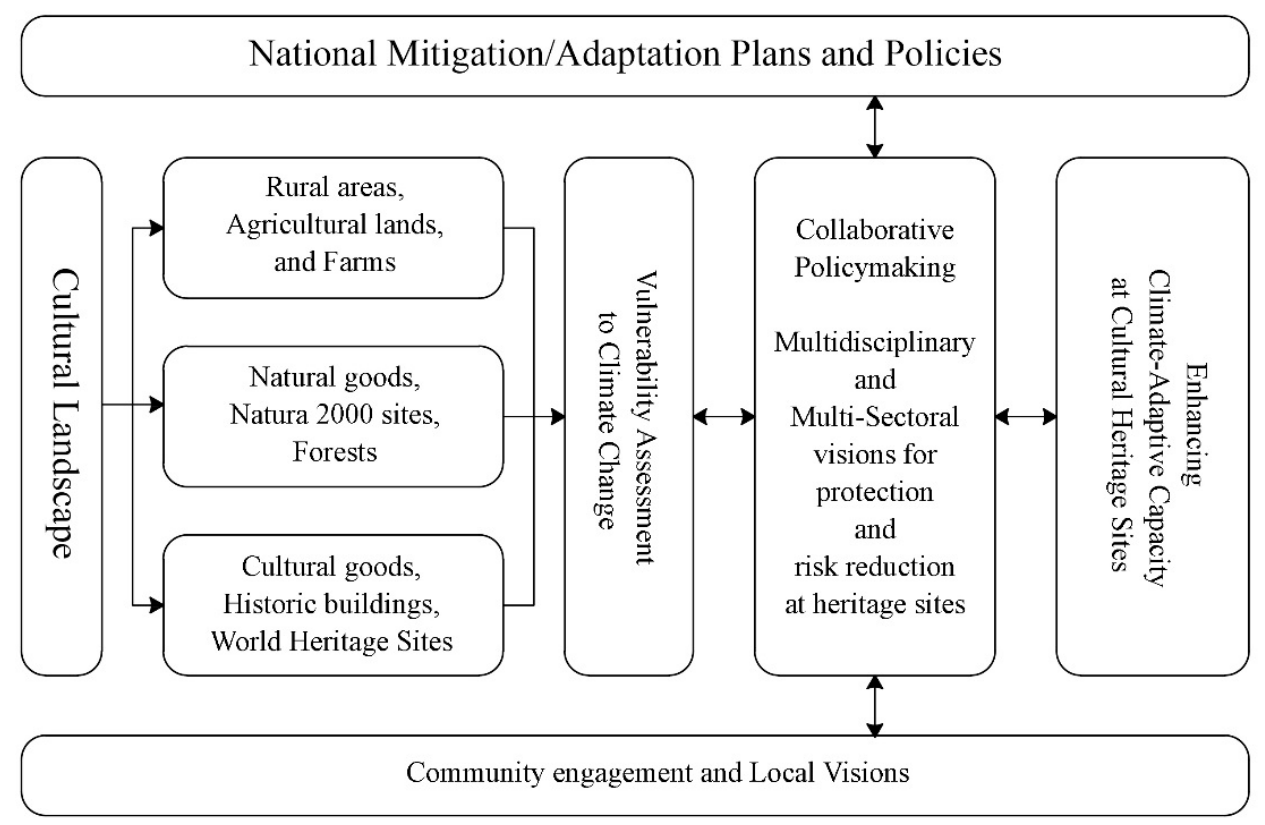

Figure 4. A framework for building adaptation capacity and sustaining of cultural landscapes in Central Italy.

Another consideration is that conservation organizations are at a different level of preparedness in terms of how well they are equipped to respond to climate change, and this condition can considerably affect the assessment, policymaking, and implementation steps. For instance, while local governments are the first responders for climate-related natural risks (e.g., flood), many municipalities may not be adequately prepared for dealing with floods. Most municipal officials have a reasonable understanding of flood issues and its adverse impact on cultural landscapes. However, they require additional information, support, and education as they deal with the complexity of decisions surrounding climate change and its impacts on heritage resources [67].

Considering the complexity of conservation issues in Central Italy in terms of climate change, the cultural and natural heritage conservation framework requires a model of how the exchanging of information should be developed among citizens, public administrators, and the scientific community at the regional scale.

\section{Conclusions}

The analysis of historical climate data shows that climate change has notably affected temperature and rainfall patterns in Italy. Many international reports forecast that Italy is going to be more vulnerable to climate change over the coming decades. In Italy, heritage resources are a driving factor for social cohesion and the national economy; thus maintenance of these resources necessitates urgent attention in developing adaptation policies at heritage sites. This study examined methods for strengthening the adaptation capacity at cultural and natural heritage sites in Central Italy. Our analysis revealed that floods and landslides are two significant climate-related risks that threaten Central Italy. However, different municipalities have different vulnerability levels to these risks based on their information and skills, and their institutional preparedness. This study further develops the concept of cultural heritage as a system of synergistic relationships between the unique qualities of the physical environment, the built environment, and the anthropic environment. Therefore, climate adaptation policies must integrate these three aspects to be effective at conserving and protecting cultural and natural heritage. In this respect, we propose the European Landscape Convention as a potential conservation framework for the development of adaptation policies in Central Italy. This convention takes a regional approach to cultural heritage that makes it distinct from the UNESCO vision. The European Landscape Convention 
takes the holistic and social landscape into consideration, while the approach of UNESCO is less regional and less place-specific in its focus. Integrating the European Landscape Convention with territorial planning also promotes communication among different sectors and stakeholders. Such a territorial vision for the conservation of heritage resources can effectively reduce the cost of climate change in terms of flood and landslide in Central Italy. Our analysis also shows that different municipalities have different levels of vulnerability to these risks based on their information and skills and institutional preparedness. One reason is that environmental organizations and public communication by scientists play a marginal role in terms of climate adaptation of cultural landscapes in Central Italy. Further research is required to understand how territorial planning can reduce organizational tensions in defining protection priorities as well as assessing stakeholder preparedness for necessary actions in terms of managing climate change and natural risks.

Author Contributions: Conceptualization, A.S.D., S.B.A.; methodology, A.S.D., S.B.A., and A.C.; writing-original draft preparation, A.S.D., S.B.A.; writing—review and editing, A.S.D., S.B.A., A.C., M.S., and G.D.L.; supervision, S.B.A., A.C., and G.D.L.; All authors have read and agree to the published version of the manuscript.

Funding: This paper was developed in the frame of Italy-USA Resilient Landscapes (RELAND), funded by the Ministry of Foreign Affairs and International Cooperation of Italy (MAECI), grant number of PGR06129.

Acknowledgments: The authors wish to express their special thanks to the US and Italian partners of the RELAND project for their precious collaboration.

Conflicts of Interest: The authors declare no conflict of interest.

\section{References}

1. Jones, M. The concept of cultural landscape: Discourse and narratives. In Landscape Interfaces; Springer: Berlin, Germany, 2003; pp. 21-51.

2. Perry, J. Climate Change Adaptation in Natural World Heritage Sites: A Triage Approach. Climate 2019, 7, 105. [CrossRef]

3. Collete, A. Climate Change and World Heritage: Report on Predicting andMmanaging the Impacts of Climate Change on World Heritage and Strategy to Assist States Parties to Implement Appropriate Management Responses. Available online: http://whc.unesco.org/document/6670 (accessed on 25 June 2019).

4. UNESCO World Heritage Center. The Operational Guidelines for the Implementation of the World Heritage Convention; UNESCO World Heritage Center: Paris, France, 2019.

5. Shirvani Dastgerdi, A.; De Luca, G. The Riddles of Historic Urban Quarters Inscription on the UNESCO World Heritage List. Int. J. Archit. Res. ArchNet-IJAR 2018, 12, 152-163. [CrossRef]

6. ICCROM European Cultural Heritage Summit-Sharing Heritage, Sharing Values. Available online: https: //www.iccrom.org/news/european-cultural-heritage-summit-sharing-heritage-sharing-values (accessed on 2 September 2019).

7. Sargolini, M. Urban landscapes and nature in planning and spatial strategies. In Nature Policies and Landscape Policies; Springer: Berlin, Germany, 2015; pp. 299-306.

8. Morandi, F.; Niccolini, F.; Sargolini, M. Parks and Territory: New Perspectives in Planning and Organization; LISt Lab Laboratorio Internazioale Editoriale: Trento, Italy, 2012.

9. Melnick, R.Z.; Kerr, N.P.; Malinay, K.; Burry-Trice, O. Climate Change and Cultural Landscapes: A Guide to Research, Planning, and Stewardship; University of Oregon Press: Eugene, OR, USA, 2017. [CrossRef]

10. Colette, A. Case Studies on Climate Change and World Heritage; UNESCO World Heritage Center: Paris, France, 2007.

11. Sabbioni, C.; Cassar, M.; Brimblecombe, P.; Tidblad, J.; Kozlowski, R.; Drdácký, M.; Saiz-Jimenez, C.; Grøntoft, T.; Wainwright, I.; Ariño, X. Global climate change impact on built heritage and cultural landscapes. In Proceedings of the Proceedings of the International Conference on Heritage, Weathering and Conservation (HWC 2006), Madrid, Spain, 21-24 June 2006.

12. Fatorić, S.; Seekamp, E. Are cultural heritage and resources threatened by climate change? A systematic literature review. Clim. Chang. 2017, 142, 227-254. [CrossRef]

13. Bertolin, C. Preservation of Cultural Heritage and Resources Threatened by Climate Change. Geosciences 2019, 9, 250. [CrossRef] 
14. Perry, J.; Falzon, C. Climate Change Adaptation for Natural World Heritage Sites: A Practical Guide; UNESCO World Heritage Center: Paris, France, 2014; Volume 37.

15. Hulme, M.; Jenkins, G.J.; Lu, X.; Turnpenny, J.R.; Mitchell, T.D.; Jones, R.G.; Lowe, J.; Murphy, J.M.; Hassell, D.; Boorman, P.; et al. Climate change scenarios for the United Kingdom: The UKCIP02 scientific report. Tyndall Centre for Climate Change Research, School of Environmental Sciences, University of East Anglia, Norwich, 2002.[Accedido 30 de Sept 2005]. Nat. Clim. Chang. 2015, 5.

16. Markham, A.; Osipova, E.; Lafrenz Samuels, K.; Caldas, A. World Heritage and Tourism in a Changing Climate. Available online: https://whc.unesco.org/document/139944 (accessed on 26 January 2020).

17. ICOMOS The Future of Our Pasts: Engaging Cultural Heritage in Climate Action. Available online: https://indd.adobe.com/view/a9a551e3-3b23-4127-99fd-a7a80d91a29e (accessed on 26 January 2020).

18. Holtz, D.; Markham, A.; Cell, K.; Ekwurzel, B. National Landmarks at Risk: How Rising Seas, Floods, and Wildfires Are Threatening the United States' Most Cherished Historic Sites; Union of Concerned Scientists: Cambridge, MA, USA, 2014.

19. IPCC Annex II: Glossary. In Climate Change 2014: Synthesis Report. Contribution of Working Groups I, II and III to the Fifth Assessment Report of the Intergovernmental Panel on Climate Change; Mach, K.J.; Planton, S.; von Stechow, C. (Eds.) IPCC Core Writing Team: Geneva, Switzerland, 2014.

20. Tsitsiragos, D. Climate Change Is a Threat-And an Opp Ortunity-For the Private Sector. Available online: https://www.worldbank.org/en/news/opinion/2016/01/13/climate-change-is-a-threat--and-an-opportunity---for-the-private-sector (accessed on 24 January 2020).

21. Georgeson, L.; Maslin, M.; Poessinouw, M.; Howard, S. Adaptation responses to climate change differ between global megacities. Nat. Clim. Chang. 2016, 6, 584. [CrossRef]

22. Dilling, L. Water security and adaptive capacity for climate: Learning lessons from drought decision making in U.S. urban contexts. AGU Fall Meet. Abstr. 2017, 2017, H13S-02.

23. Allen, M.R.; Dube, O.P.; Solecki, W.; Aragón-Durand, F.; Cramer, W.; Humphreys, S.; Kainuma, M.; Kala, J.; Mahowald, N.; Mulugetta, Y.; et al. Framing and Context. In Global Warming of $1.5^{\circ} \mathrm{C}$. An IPCC Special Report on the Impacts of Global Warming of $1.5^{\circ} \mathrm{C}$ above Pre-Industrial Levels and Related Global Greenhouse Gas Emission Pathways, in the Context of Strengthening the Global Response to the Threat of Climate Change; Masson-Delmotte, V., Zhai, P., Pörtner, H.-O., Roberts, D., Skea, J., Shukla, P.R., Pirani, A., Moufouma-Okia, W., Péan, C., Pidcock, R., et al., Eds.; IPCC: Paris, France, 2018.

24. Siders, A.R. Adaptive capacity to climate change: A synthesis of concepts, methods, and findings in a fragmented field. Wiley Interdiscip. Rev. Clim. Chang. 2019, 10, e573. [CrossRef]

25. Shirvani Dastgerdi, A.; Sargolini, M.; Pierantoni, I. Climate Change Challenges to Existing Cultural Heritage Policy. Sustainability 2019, 11, 5227. [CrossRef]

26. Denton, F.; Wilbanks, T.J.; Abeysinghe, A.C.; Burton, I.; Gao, Q.; Lemos, M.C.; Masui, T.; O’Brien, K.L.; Warner, K.; Bhadwal, S.; et al. Climate-Resilient Pathways: Adaptation, Mitigation, and Sustainable Development; IPCC: Paris, France, 2015.

27. Sesana, E.; Gagnon, A.S.; Bertolin, C.; Hughes, J. Adapting cultural heritage to climate change risks: Perspectives of cultural heritage experts in europe. Geosciences 2018, 8, 305. [CrossRef]

28. Posey, J. The determinants of vulnerability and adaptive capacity at the municipal level: Evidence from floodplain management programs in the United States. Glob. Environ. Chang. 2009, 19, 482-493. [CrossRef]

29. Engle, N.L.; Lemos, M.C. Unpacking governance: Building adaptive capacity to climate change of river basins in Brazil. Glob. Environ. Chang. 2010, 20, 4-13. [CrossRef]

30. Smit, B.; Pilifosova, O. From adaptation to adaptive capacity and vulnerability reduction. In Climate Change, Adaptive Capacity and Development; IPCC: Paris, France, 2003; ISBN 9781860945816.

31. ESPON CLIMATE. Climate Change and Territorial Effects on Regions and Local Economies; ESPON CLIMATE: Luxembourg, 2010.

32. Sesana, E.; Bertolin, C.; Loli, A.; Gagnon, A.S.; Hughes, J.; Leissner, J. Increasing the Resilience of Cultural Heritage to Climate Change Through the Application of a Learning Strategy. Int. Conf. Transdiscipl. Multispectral Model. Coop. Preserv. Cult. Herit. 2018, 402-423.

33. Yale program on Climate Change Communication. Available online: https://climatecommunication.yale.edu/ (accessed on 15 September 2019).

34. OCED. Water and Climate Change Adaptation: Policies to Navigate UnchartedWaters; OECD Studies on Water; OECDt: Geneva, Switzerland, 2013; ISBN 9789264200432. 
35. Galeotti, M.; Roson, R. Economic Impacts of Climate Change in Italy and the Mediterranean: Updating the Evidence. J. Sustain. Dev. 2012, 5, 27-41. [CrossRef]

36. World Bank Italy. Available online: https://climateknowledgeportal.worldbank.org/country/italy (accessed on 11 September 2019).

37. Pinault, J.-L. Anthropogenic and Natural Radiative Forcing: Positive Feedbacks. J. Mar. Sci. Eng. 2018, 6, 146. [CrossRef]

38. Ministry for the Environment, Land and Sea. Vulnerability Assessment, Climate Change Impacts and Adaptation Measures-Convention on Climate Change Italy; Ministry for the Environment, Land and Sea: Rome, Italy, 2009.

39. Ministry of the Environment and Land Protection Flood Risk Management in Italy: Tools for the Hydrogeological Land Llanning. Available online: https://www.minambiente.it/sites/default/files/archivio/ biblioteca/ds_flood_risk_management_vienna17_18_05_2006.pdf (accessed on 15 September 2019).

40. Peter Sommer Travels Italian Geography. Available online: https:/www.petersommer.com/italy/geography (accessed on 26 January 2020).

41. World Heritage Centre World Heritage List Statistics. Available online: https://whc.unesco.org/en/list/stat/ (accessed on 1 October 2019).

42. World Heritage Centre Interactive Map. Available online: https://whc.unesco.org/en/interactive-map/ (accessed on 6 January 2020).

43. World Heritage Centre World Heritage List. Available online: https://whc.unesco.org/en/list (accessed on 8 September 2019).

44. UNESCO World Heritage Center Val d'Orcia. Available online: http://whc.unesco.org/en/list/1026 (accessed on 26 January 2020).

45. UNESCO World Heritage Centre Villa d'Este, Tivoli. Available online: http://whc.unesco.org/en/list/1025 (accessed on 26 January 2020).

46. Ministero per i Beni e le Attività Culturali Legislative Decree No. 42 of 22 January 2004- Code of the Cultural and Landscape Heritage. Available online: https://sherloc.unodc.org/res/cld/document/ita/code-of-thecultural-and-landscape-heritage_html/it_cult_landscapeheritge2004_engtof.pdf (accessed on 26 January 2020).

47. UNESCO Convention Concerning the Protection of the World Cultural and Natural Heritage. Available online: https://whc.unesco.org/en/conventiontext/ (accessed on 26 January 2020).

48. Sauer, C.O. The Morphology of Landscape. Univ. Calif. Publ. Geogr. 1925, 22, 19-53.

49. World Heritage Centre. Operational Guidelines for the Implementation of the World Heritage Convention; UNESCO World Heritage Centre: Paris, France, 1999.

50. Council of Europe. European Landscape Convention; Council of Europe: Strasbourg, France, 2000.

51. Trusiani, E. Cultural Landscape. In Landscape: Between Conservation and Transformation; Biscotto, E., D'Astoli, S.B., Trusian, E., Eds.; Gangemi: Rome, Italy, 2013.

52. Shirvani Dastgerdi, A.; De Luca, G. Specifying the Significance of Historic Sites in Heritage Planning. Conserv. Sci. Cult. Herit. 2018, 18, 29-39.

53. Amoruso, G.; Salerno, R. Cultural Landscape in Practice; Springer: Berlin, Germany, 2019.

54. Sargolini, M. Mountain Landscapes; University of Camerino: Camerino, Italy, 2016; ISBN 9788898774388.

55. ISTAT Temperature and Precipitation in the Main Cities. Available online: https://www.istat.it/it/archivio/ 217402 (accessed on 2 January 2020).

56. Bartolini, G.; Morabito, M.; Crisci, A.; Grifoni, D.; Torrigiani, T.; Petralli, M.; Maracchi, G.; Orlandini, S. Recent trends in Tuscany (Italy) summer temperature and indices of extremes. Int. J. Climatol. A J. R. Meteorol. Soc. 2008, 28, 1751-1760. [CrossRef]

57. World Bank Climate Data. Available online: https://climateknowledgeportal.worldbank.org/country/italy/ climate-data-historical (accessed on 1 September 2019).

58. Normativa nazionale Legge 3 agosto 1998, n. 267. Available online: http://www.edizionieuropee.it/LAW/ HTML/4/zn17_03_163.html (accessed on 1 September 2019).

59. Sgobbi, A.; Carraro, C. Climate Change Impacts and Adaptation Strategies in Italy: An Economic Assessment; FEEM Fondazione Eni Enrico Mattei Reseach Paper; Fondazione Eni Enrico Mattei (FEEM): Milan, Italy, 2008. 
60. ISTAT Hydrogeological Instability in Italy: Hazard and Risk Indicators. Available online: http://www.isprambiente.gov.it/it/pubblicazioni/rapporti/dissesto-idrogeologico-in-italia-pericolosita-eindicatori-di-rischio-rapporto-2015 (accessed on 2 January 2020).

61. Perna, P.; Pierantoni, I.; Renzi, A.; Sargolini, M. SUN LIFE: Strategy for managing the Natura 2000 network in Umbria; LIST Laboratorio: Roma, Italy, 2018; ISBN 9788899854331.

62. Beltrame, L.; Bucchi, M.; Loner, E. Climate Change Communication in Italy. In Oxford Research Encyclopedia of Climate Science; Oxford University Press: Oxford, UK, 2017.

63. Asghar, S.; Alahakoon, D.; Churilov, L. A comprehensive conceptual model for disaster management. J. Humanit. Assist. 2006, 1360, 1-15.

64. Shirvani Dastgerdi, A.; Stimilli, F.; Pisano, C.; Sargolini, M.; De Luca, G. Heritage waste management: A possible paradigm shift in post-earthquake reconstruction in central Italy. Cult. Herit. Manag. Sustain. Dev. 2019, 1-17. [CrossRef]

65. Harvey, D.C.; Perry, J. The Future of Heritage as Climates Change: Loss, Adaptation and Creativity; Routledge: London, UK, 2015; ISBN 9781317530121.

66. Magnaghi, A. Il progetto locale: Verso la coscienza di luogo; Bollati Boringhieri: Turin, Italy, 2013.

67. Gary, G.; Allred, S.B.; LoGiudice, E.; Chatrchyan, A.; Baglia, R.; Mayhew, T.; Olsen, D.; Wyman, M. Community Adaptation to Flooding in a Changing Climate: Municipal Officials' Actions Decision-Making and Barriers. Res. Policy Br. Ser. 2013.

(C) 2020 by the authors. Licensee MDPI, Basel, Switzerland. This article is an open access article distributed under the terms and conditions of the Creative Commons Attribution (CC BY) license (http://creativecommons.org/licenses/by/4.0/). 